\title{
Toxicity (acute and subacute) assessment and in-vivo antiurolithiatic activity of ethanolic extract of Caesalpinia bonducella seed in albino Wistar rat
}

\author{
Ajay Kumar ${ }^{1}$ (D) , Manmath Kumar Nandi² ${ }^{2}$, Brijesh Kumar ${ }^{1 *}$, Ashutosh Kumar ${ }^{1}$, Rajesh Kumar ${ }^{1}$ \\ Ambrish Kumar Singh ${ }^{4}$ \\ ${ }^{1}$ Department of Pharmacology, Faculty of Modern Medicine, Institute of Medical Sciences BHU, Varanasi, India. \\ ${ }^{2}$ Department of Medicinal Chemistry, Institute of Medical Sciences BHU, Varanasi, India. \\ ${ }^{3}$ Department of Pathology, Faculty of Modern Medicine, Institute of Medical Sciences, Banaras Hindu, Varanasi, UP, India. \\ ${ }^{4}$ Pharmacy Ayurveda, Rajiv Gandhi South Campus Banaras Hindu, Mirzapur, India.
}

\section{ARTICLE INFO \\ Received on: 09/07/2021 \\ Accepted on: 17/11/2021 \\ Available Online: 05/02/2022}

Key words:

Stone, calcium oxalate, ethylene glycol, sodium oxalate, nephrolithiasis.

\begin{abstract}
The objective of the present work is to find supportive evidence for the use of Caesalpinia bonducella in nephrolithiasis. For safety assessment of ethanolic extract of seed of $C$. bonducella $(\mathrm{ECB})$, acute and subacute oral toxicity studies was performed. In the acute oral toxicity study at a dose of $2,000 \mathrm{mg} / \mathrm{kg}$ and subacute oral toxicity study at dose of 250 , 500 , and $1,000 \mathrm{mg} / \mathrm{kg}$, no changes were seen in the behavior, haematological parameters, biochemical parameters, histopathology of major organ, and body weight of rats. The efficacy of ECB at dose of $200 \mathrm{and} 400 \mathrm{mg} / \mathrm{kg}$ was studied in ethylene glycol, glycolic acid, and sodium oxalate induced urolithiasis in rats and marketed cystone tablet at a dose of $750 \mathrm{mg} / \mathrm{kg}$ was used as the standard drug. The mean body weight difference, urinary parameters (urine $\mathrm{pH}$, urine volume, levels of calcium, magnesium, and phosphorus), and serum biochemical parameters [urea, Blood urea nitrogen (BUN), creatinine, uric acid, and alkaline phosphatase] were measured. Urolithiasis caused a significant decrease in mean body weight, $\mathrm{pH}$, and volume of urine and increased in both serum biochemical parameters and urinary electrolyte concentration as compared with the normal control group. Histopathology of kidneys were showed increased glomerular hypercellularity, hydropic tubular degeneration, and cast in the induced control group. Ethanolic Extract of Caesalpinia bonducella (ECB) was found to be effective to normalise the above all changes. It was concluded that the ECB was effective in the prevention and elimination of calcium oxalate crystal deposition into kidneys.
\end{abstract}

\section{INTRODUCTION}

Urolithiasis also termed kidney stone or nephrolithiasis, is a common worldwide disease with a high prevalence and recurrence rate. Chronic diseases, including diabetes mellitus, obesity, kidney disease, metabolic disorder, and hypertension, have a high tendency to form stones compared with healthy people (Besiroglu and Ozbek, 2019). It causes pyelonephritis or acute renal failure and severe acute back pain (Namburu et al.,

\footnotetext{
*Corresponding Autho

Brijesh Kumar, Department of Pharmacology, Faculty of Modern Medicine, Institute of Medical Sciences BHU, Varanasi, India.E-mail: asthwal @ rediffmail.com
}

2017; Yasui et al., 2017). Urolithiasis typically occurs between the age of 20 and 60 years and is more occurrences in hot climates. It affects nearly $10 \%$ of men and $6 \%$ of women over their lifetime. The recurrence rate is $50 \%$ within $5-10$ years and $75 \%$ within 20 years of initial treatment (Dawson and Tomson, 2012; Yasui et al., 2017). The overall recurrence rate is high in male $(70 \%-80 \%)$ as compared with female $(47 \%-60 \%)$ (Ahmed et al., 2018; Wang et al., 2019). Approximately, 80\% of stones are calcium-containing stones which are found as pure calcium oxalate $(\mathrm{CaOx})(50 \%)$, pure calcium phosphate $(1 \%)$, or a mixture of both (45\%), and other stones are struvite (10\%), uric acid $(9 \%)$, and cystine (1\%) (Bashir and Gilani, 2009; Namburu et al., 2017). $\mathrm{CaOx}\left(\mathrm{CaC}_{2} \mathrm{O}_{4}\right)$ stones are found as $\mathrm{CaOx}$ monohydrate or $\mathrm{CaOx}$ dehydrate form. Struvite stones are also called triple phosphate or infection stones or magnesium ammonium phosphate and develop 
when the urease-producing bacteria such as proteus cause the urine $\mathrm{pH}$ higher than 7.2 by ammonia (urea convert in ammonia in presence of urease enzyme) (Ahmed et al., 2018).

Caesalpinia bonducella Roxb. (Caesalpiniaceae) is extensively used in the traditional medicine (Bawari et al., 2020; Bashir and Gilani, 2009; Datte et al., 1998; Iheagwam et al., 2019; Liu et al., 2020). The various parts of $C$. bonducella have been reported for anti-cancer and cytotoxic activities (Iheagwam et al., 2019); contractile activity of uterine smooth muscle (Datte et al., 1998); inhibit nuclear factor-kappa B and type-4 phosphodiesterase (Liu et al., 2020); antimicrobial activities (Arif et al., 2009). The objective of this study is to perform toxicity study (acute and subacute oral toxicity) and to evaluate antiurolithiatic activity of ECB in experimentally induced $\mathrm{CaOx}$ stone model.

\section{MATERIALS AND METHODS}

\section{Material}

Chemicals of analytical grade were utilized in the studies. Cystone was procured from Varanasi's local market. Albumin, total protein, calcium, phosphorous, magnesium, uric acid, urea, creatinine, uric acid estimation kits were procured from Coral Clinical Systems, a division of Tulip Diagnostics (P) Ltd., Uttarakhand, India. Alkaline phosphatase (ALP), aspartate aminotransferase (AST), alanine aminotransferase (ALT) were procured from Autospan Liquid Gold, Arkray Healthcare Pvt. Ltd., Maharastra, India. UV-Visible spectrophotometer (Systronics Double Beam UV-VIS Spectrophotometer: 2202) was used for analysis.

\section{Plant material and extraction}

The plant seeds samples were collected from the local market in Varanasi, India. A voucher specimen was deposited (number 201901) and authenticated by Dr. Ashwani K. Kushwaha, Department of Dravyguna, Faculty of Ayurveda, Institute of Medical Sciences (IMS), Banaras Hindu University (BHU), Varanasi. The coarsely powdered seeds of C. bonducella $(100 \mathrm{~g})$ were soaked in 11 of $95 \%$ ethanol for a week with occasional shaking. The crude extract was obtained by filtration through filter paper. The filtrate was evaporated by rotatory evaporator to give a viscous brownish dark mass and the extract was preserved in a refrigerator at $2{ }^{\circ} \mathrm{C}-8^{\circ} \mathrm{C}$ for use in the experiments (Bashir and Gilani, 2009). The yield value of the extract was $6 \%(\mathrm{w} / \mathrm{w})$. The extract was suspended in $0.5 \%$ carboxy methyl cellulose (CMC) for pharmacological screening.

\section{Animals}

Adult albino Wistar rats, 12 weeks old, 130-150 g bodyweight, were used for the study. They were placed under standard conditions $\left(22^{\circ} \mathrm{C} \pm 3^{\circ} \mathrm{C}\right)$ and allowed free access to standard food pellets and water. After 1 week of acclimatization, rats were used for the experiment. Rats were handled according to the Committee for the Purpose of Control and Supervision of Experiments on Animals (CPCSEA) guidelines and procedures were approved by the ethical committee of the Institute of Medical
Sciences, BHU, Varanasi, India $(2211,07.11 .2020)$ for the care and use of Laboratory Animals.

\section{Toxicity study}

Acute oral toxicity

The acute toxicity was performed according to the Organisation for Economic Co-operation and Development (OECD) (423, December 17, 2001) test guidelines. Rats were divided into two groups $(n=3)$. Group I (control) received p.o. vehicle $(0.5 \% \mathrm{CMC})$, while Group II was treated with ECB at a single dose of 2,000 mg/kg p.o.

\section{Subacute oral toxicity}

The subacute toxicity was performed according to the OECD (407, October 3, 2008) guidelines with slight modification. Rats were divided into four groups $(n=5)$. Group I (control) received vehicle orally $(0.5 \% \mathrm{CMC})$, while Group II, III, and IV received orally 250,500 , and $1,000 \mathrm{mg} / \mathrm{kg}$ per day dose of $\mathrm{ECB}$, respectively, for 28 consecutive days (Ekanayake et al., 2019; Hasan et al., 2020; Kharchoufa et al., 2020; Loha et al., 2019; Meguellati et al., 2019; Porwal et al., 2017; Silva et al., 2011).

\section{Behavioral changes and mortality}

Animals were observed for food intake, water intake, bodyweight, behavioral changes, seizure, hair loss, allergic reaction, hazardous symptoms, and number of deaths during the entire experiment.

\section{Hematological and biochemical analysis}

Animals were anesthetized with chloroform once the toxicity investigation was completed, and blood was taken via retro-orbital puncture with Ethylenediamine tetraacetic acid (EDTA) coated capillary tube. Hematological parameters were determined by Auto-Haematology analyser (Arkray Autocell Plus). The serum parameters were determined by using standard diagnostic kits.

\section{Histopathological studies}

After completion of toxicity study duration, all animals were anesthetized with chloroform and sacrificed. The organs, like liver, heart, lungs, and kidney, were collected and preserved in $10 \%$ formalin solution. The preserved organs were fixed in melted paraffin wax, then allowed to solidify. The tissue sections were prepared using a microtome (thickness of $4 \mu \mathrm{m}$ ). After staining with hematoxylin and eosin, the pathological changes of the tissue sections were examined and identified under microscope [Olympus Magnus Inverted (INVI) inverted microscope] in comparison with the control group (Ekanayake et al., 2016).

\section{In vivo urolithiasis}

\section{Ethylene glycol (EG) induced urolithiasis}

The antiurolithiasis activity of ECB was evaluated by EG induced urolithiasis model (Bawari et al., 2020; Lonkala, 2020; Moriyama et al., 2009; Patel and Acharya, 2020; Tzou et al., 2016) with slight modification. Animals were divided into five groups $(n=5)$. Group I (normal control) received p.o. vehicle $(0.5 \%$ CMC) for 28 days. Group II, III, IV, and V received p.o. 
$0.75 \% \mathrm{v} / \mathrm{v}$ EG and $1 \% \mathrm{w} / \mathrm{v}$ ammonium chloride for 28 days. Group II (induced control) received vehicle $0.5 \% \mathrm{CMC}$ p.o. once daily from 15 th day to 28 th day. Group III, IV, and V received p.o. $200,400 \mathrm{mg} / \mathrm{kg}$ dose of ECB and $750 \mathrm{mg} / \mathrm{kg}$ dose of cystone tablet (a standard polyherbal formulation), respectively, once daily from 15 th day to 28 th day.

\section{Sodium oxalate (SO) induced urolithiasis}

The antiurolithiasis activity of ECB was evaluated by SO induced urolithiasis model (Araujo et al., 2020; Elhan et al., 2014; Tzou et al., 2016) with slight modification. Rats were divided into five groups $(n=5)$. Group I (normal control) received vehicle $0.5 \%$ CMC p.o. once daily for 21 days. Group II, III, IV, and $\mathrm{V}$ received SO (70 mg/kg per day, i.p.) for 7 days. Group II (induced control group) received vehicle $0.5 \% \mathrm{CMC}$ p.o. once daily for next 14 days. Group III, IV, and V received p.o. 200, 400 $\mathrm{mg} / \mathrm{kg}$ dose of ECB and $750 \mathrm{mg} / \mathrm{kg}$ dose of cystone, respectively, once daily for next 14 days.

\section{Glycolic acid (GA) induced urolithiasis}

The antiurolithiasis activity of ECB was evaluated by GA induced urolithiasis model (Mitra et al., 1998; Sathya and Kokilavani, 2012; Shehzad et al., 2021; Tzou et al., 2016) with slight modification. The rats were divided into five groups $(n=5)$. Group I (normal control) received vehicle $0.5 \%$ CMC p.o. once daily for 21 days. Group II, III, IV, and V received 3\% v/v GA per day, p.o. for 7 days. Group II (induced control) received vehicle $0.5 \%$ CMC p.o. once daily from for next 14 days. Group III, IV, and $\mathrm{V}$ received p.o. 200, $400 \mathrm{mg} / \mathrm{kg}$ dose of ECB and $750 \mathrm{mg} / \mathrm{kg}$ dose of cystone, respectively, once daily for next 14 days.

\section{Body weight}

In EG induced urolithiatic model, changes in bodyweight of individual rats were measured on the 1st, 14th, and 28th days while, in the GA and SO induced urolithiatic model, the body weight was measured on 1st, 7 th and 21 st days.

\section{Urine analysis}

At the end of experiment, all animals were kept in metabolic case for 24 hours urine collection. A drop of conc. Hydrochloric acid $(\mathrm{HCl})$ was mixed in urine to prevent microbial growth (Patel and Acharya, 2020). Urine samples were used to measurement of urine volume and then quantitative estimation of calcium, phosphorus, and magnesium. Urine $\mathrm{pH}$ was analyzed by pH meter (Eutech Instruments CyberScan pH 510)

\section{Biochemical analysis}

Animals were anesthetized with chloroform once the toxicity investigation was completed, and blood was taken via retro-orbital puncture with capillary. After centrifugation at 5,000 $\mathrm{g}$ for 15 minutes, serum was collected and stored in a deep freezer (Patel and Acharya, 2020). The serum parameters were determined by using diagnostic kits.

\section{Histopathological studies}

At the end of experiment, all rats were anesthetized with chloroform and sacrificed and the kidneys were collected and preserved in $10 \%$ formalin. Kidney sections were prepared as the above-described procedure. The pathological changes in kidney sections were identified by comparison with control group and photographs were taken by microscope (Olympus Magnus INVI inverted microscope).

\section{Statistical analysis}

The data were expressed as mean \pm SEM and analyzed by using software GraphPad Prism 8.0.2. ordinary one-way and two-way analysis of variance with Dunnett's multiple comparisons test was applied.

\section{RESULTS AND DISCUSSION}

In order to investigate the effect of medicinal plants on urolithiasis, we chosen $C$. bonducella that have been claimed to have diverse therapeutic characteristics. Extraction of $C$. bunducella seed were performed in ethanol (95\%) based on the literature studies stating that ethanol (95\%) can offer superior extraction results for phenolic like chemicals because it dissolves the most polar and non-polar compounds. Extraction was done using the cold percolation process, and the operation was repeated three times with new solvents for a greater yield. Semisolid extracts were obtained and kept in the freezer for scientific investigations. In this investigation, ethanolic solvent yielded higher extract yields for C. bonducella (6\%).

The signs and symptoms of toxicity, including morbidity or mortality, were not observed in both acute and subacute oral toxicity. $\mathrm{LD}_{50}$ of ECB could be greater than $2,000 \mathrm{mg} / \mathrm{kg}$ because

Table 1. Effects of C. bonducella extract on haematological parameters in acute oral toxicity study.

\begin{tabular}{|c|c|c|}
\hline Parameter & Control & $2,000 \mathrm{mg} / \mathrm{kg}$ \\
\hline $\mathrm{Hb}(\mathrm{g} / \mathrm{dl})$ & $14.63 \pm 0.43$ & $14.57 \pm 0.38^{*}$ \\
\hline $\operatorname{PCV}(\%)$ & $46.23 \pm 0.87$ & $46.09 \pm 1.24^{*}$ \\
\hline $\mathrm{RBC}$ count $\left(\mathrm{mill} / \mathrm{mm}^{3}\right)$ & $9.16 \pm 0.22$ & $8.55 \pm 0.38^{*}$ \\
\hline $\operatorname{MCV}(\mathrm{fl})$ & $50.51 \pm 0.75$ & $54.01 \pm 0.97^{*}$ \\
\hline $\mathrm{MCH}(\mathrm{pg})$ & $15.98 \pm 0.15$ & $17.15 \pm 1.21^{*}$ \\
\hline $\operatorname{MCHC}(\mathrm{g} / \mathrm{dl})$ & $31.64 \pm 0.46$ & $31.69 \pm 1.66^{*}$ \\
\hline RDW (\%) & $22.21 \pm 0.98$ & $23.02 \pm 0.95^{*}$ \\
\hline TLC (thou $/ \mathrm{mm}^{3}$ ) & $11.04 \pm 0.71$ & $9.82 \pm 0.51^{*}$ \\
\hline Segmented neutrophils (\%) & $15.13 \pm 0.10$ & $13.72 \pm 1.37^{*}$ \\
\hline Lymphocytes (\%) & $79.28 \pm 0.61$ & $81.56 \pm 1.02^{*}$ \\
\hline Monocytes (\%) & $2.65 \pm 0.25$ & $2.00 \pm 0.55^{*}$ \\
\hline Eosinophils (\%) & $2.62 \pm 0.74$ & $2.27 \pm 0.62^{*}$ \\
\hline Basophils (\%) & $0.32 \pm 0.11$ & $0.46 \pm 0.22^{*}$ \\
\hline Neutrophils (thou $/ \mathrm{mm}^{3}$ ) & $1.67 \pm 0.10$ & $1.36 \pm 0.20^{*}$ \\
\hline Lymphocytes (thou/ $/ \mathrm{mm}^{3}$ ) & $8.76 \pm 0.61$ & $8.01 \pm 0.41^{*}$ \\
\hline Monocytes (thou/mm³) & $0.30 \pm 0.05$ & $0.19 \pm 0.05^{*}$ \\
\hline Eosinophils (thou $/ \mathrm{mm}^{3}$ ) & $0.28 \pm 0.07$ & $0.22 \pm 0.05^{*}$ \\
\hline Basophils (thou/mm³) & $0.04 \pm 0.01$ & $0.04 \pm 0.02^{*}$ \\
\hline Platelets (thou/mm³) & $858.33 \pm 11.05$ & $861.67 \pm 16.50^{*}$ \\
\hline Mean platelet volume(fl) & $8.13 \pm 0.33$ & $7.97 \pm 0.28^{*}$ \\
\hline
\end{tabular}

$\mathrm{Hb}$, Haemoglobin; PVC, Packed cell volume; MCV, Mean corpuscular volume; $\mathrm{MCH}$, Mean corpuscular hemoglobin; MCHC, Mean corpuscular hemoglobin concentration; TLC, Total leucocytes count; RDW, Red cell distribution width; WBC, White blood cell; MPV, Mean platelet volume.

Values represent the mean $\pm \operatorname{SEM}(n=3)$.

${ }^{*} p>0.05$. 
Table 2. Effects of $C$. bonducella extract on biochemical parameters in acute oral toxicity study.

\begin{tabular}{ccc}
\hline Parameter & Control & $\mathbf{2 , 0 0 0 ~} \mathbf{~ g} / \mathbf{k g}$ \\
\hline Urea $(\mathrm{mg} / \mathrm{dl})$ & $24.20 \pm 1.58$ & $25.79 \pm 1.09^{*}$ \\
Uric acid (mg/dl) & $2.50 \pm 0.75$ & $2.46 \pm 0.76^{*}$ \\
Creatinine (mg/dl) & $0.56 \pm 0.14$ & $0.60 \pm 0.10^{*}$ \\
ALP (U/l) & $134.05 \pm 1.57$ & $134.33 \pm 2.12^{*}$ \\
AST (U/l) & $74.87 \pm 1.14$ & $74.33 \pm 1.24^{*}$ \\
ALT (U/l) & $45.74 \pm 1.53$ & $45.72 \pm 1.54^{*}$ \\
Albumin (mg/dl) & $3.90 \pm 0.13$ & $3.73 \pm 0.31^{*}$ \\
Globulin (mg/dl) & $3.44 \pm 0.06$ & $3.45 \pm 0.22^{*}$ \\
Total protein & $7.34 \pm 0.19$ & $7.18 \pm 0.53^{*}$ \\
Albumin/globulin ratio & $1.13 \pm 0.02$ & $1.08 \pm 0.03^{*}$ \\
Initial wt (g) & $143.50 \pm 1.95$ & $141.67 \pm 2.06^{*}$ \\
1 week (g) & $148.33 \pm 1.74$ & $146.83 \pm 1.58^{*}$ \\
2 weeks (g) & $154.00 \pm 1.67$ & $152.33 \pm 1.65^{*}$ \\
BWG (g) & $10.50 \pm 0.56$ & $10.67 \pm 0.88^{*}$ \\
Food intake (g/day) & $23.50 \pm 0.99$ & $23.83 \pm 1.05^{*}$ \\
Water intake (ml/day) & $30.17 \pm 1.28$ & $27.67 \pm 0.99^{*}$ \\
\hline
\end{tabular}

AST, Aspartate aminotransferase; ALT, Alanine aminotransferase; ALP, Alkaline phosphatase; BWG, Bodyweight gain.

Values represent the mean $\pm \operatorname{SEM}(n=3)$.

$* p>0.05$. there was no death recorded in rats during treatment. In acute and subacute toxicity study, the bodyweight of both the treated and normal control group were gradually increased and no significant change in mean body weight gain (Table 2 and 4). The results of hematological and biochemical parameters of treated groups were showed non-significant $(p>0.05)$, similar and within range as compared with normal control group in both acute (Table 1 and 2 ) and subacute oral toxicity study (Table 3 and 4). The results of hematological and biochemical parameters of all groups were found to be normal and nearly similar to previously reported studies (Han et al., 2015; Porwal et al., 2017; Silva et al., 2011). The histopathology of the liver showed no inflammation, normal hepatocytes cords, no acute or chronic damage in both acute (Fig. 1D), and subacute oral toxicity (Fig. 4) study. The histopathology of the kidney showed normal glomeruli, tubules, vessels with no features of damage or inflammation in both acute (Fig. 1A), and subacute oral toxicity (Fig. 2). The section of lungs showed normal patent alveoli lined by pneumocytes and there is no collapse, exudate, inflammatory infiltrate, or necrosis in the lung parenchyma in both acute (Fig. 1B) and subacute oral toxicity (Fig. 3). The section of the heart showed cardiomyocytes arranged in pseudosyncytium with normal thickness and there is no myonecrosis or inflammation in both acute (Fig. 1C) and subacute oral toxicity (Fig. 5).

In EG, GA, and SO-induced urolithiasis model, the bodyweight of both $C$. bonducella and cystone-treated groups was increased significantly $(p<0.01$ to $p<0.0001)$ as compared

Table 3. Effects of C. bonducella extract on haematological parameters in subacute oral toxicity study.

\begin{tabular}{|c|c|c|c|c|}
\hline Parameters & Control & $250 \mathrm{mg} / \mathrm{kg}$ & $500 \mathrm{mg} / \mathrm{kg}$ & $1,000 \mathrm{mg} / \mathrm{kg}$ \\
\hline $\mathrm{Hb}(\mathrm{g} / \mathrm{dL})$ & $14.57 \pm 0.20$ & $14.37 \pm 0.33^{*}$ & $13.82 \pm 0.45^{*}$ & $14.17 \pm 0.38^{*}$ \\
\hline PCV (\%) & $47.30 \pm 0.23$ & $45.53 \pm 1.80^{*}$ & $45.80 \pm 0.97^{*}$ & $46.64 \pm 0.90^{*}$ \\
\hline $\mathrm{RBC}$ count $\left(\mathrm{mill} / \mathrm{mm}^{3}\right)$ & $9.28 \pm 0.16$ & $8.53 \pm 0.31^{*}$ & $8.88 \pm 0.18^{*}$ & $9.13 \pm 0.19^{*}$ \\
\hline MCV (fL) & $51.02 \pm 0.82$ & $53.64 \pm 3.60^{*}$ & $51.57 \pm 0.25^{*}$ & $51.07 \pm 0.35^{*}$ \\
\hline $\mathrm{MCH}(\mathrm{pg})$ & $15.72 \pm 0.45$ & $16.88 \pm 0.47^{*}$ & $15.56 \pm 0.46^{*}$ & $15.52 \pm 0.33^{*}$ \\
\hline $\mathrm{MCHC}(\mathrm{g} / \mathrm{dl})$ & $30.80 \pm 0.39$ & $31.72 \pm 2.03^{*}$ & $30.17 \pm 0.76^{*}$ & $30.38 \pm 0.45^{*}$ \\
\hline RDW (\%) & $22.23 \pm 0.55$ & $23.49 \pm 0.33^{*}$ & $22.52 \pm 0.47^{*}$ & $22.45 \pm 0.44^{*}$ \\
\hline TLC (thou $/ \mathrm{mm}^{3}$ ) & $11.10 \pm 0.63$ & $9.44 \pm 0.27^{*}$ & $11.11 \pm 0.59^{*}$ & $10.70 \pm 0.26^{*}$ \\
\hline Segmented neutrophils (\%) & $15.57 \pm 0.80$ & $13.43 \pm 1.85^{*}$ & $15.81 \pm 0.28^{*}$ & $14.99 \pm 2.72^{*}$ \\
\hline Lymphocytes (\%) & $79.79 \pm 1.55$ & $81.61 \pm 1.61^{*}$ & $79.14 \pm 0.30^{*}$ & $80.01 \pm 3.58^{*}$ \\
\hline Monocytes (\%) & $2.33 \pm 0.52$ & $2.34 \pm 0.62^{*}$ & $2.50 \pm 0.29^{*}$ & $2.21 \pm 0.68^{*}$ \\
\hline Eosinophils (\%) & $2.06 \pm 0.47$ & $2.15 \pm 0.33^{*}$ & $2.23 \pm 0.30^{*}$ & $2.34 \pm 0.59^{*}$ \\
\hline Basophils (\%) & $0.24 \pm 0.11$ & $0.46 \pm 0.10^{*}$ & $0.32 \pm 0.12^{*}$ & $0.44 \pm 0.18^{*}$ \\
\hline Neutrophils (thou/mm $\mathrm{mm}^{3}$ ) & $1.72 \pm 0.09$ & $1.26 \pm 0.15^{*}$ & $1.75 \pm 0.07^{*}$ & $1.59 \pm 0.26^{*}$ \\
\hline Lymphocytes (thou/ $/ \mathrm{mm}^{3}$ ) & $8.86 \pm 0.54$ & $7.71 \pm 0.38^{*}$ & $8.79 \pm 0.43^{*}$ & $8.58 \pm 0.58^{*}$ \\
\hline Monocytes (thou/mm³) & $0.26 \pm 0.06$ & $0.22 \pm 0.06^{*}$ & $0.28 \pm 0.04^{*}$ & $0.23 \pm 0.07^{*}$ \\
\hline Eosinophils (thou $/ \mathrm{mm}^{3}$ ) & $0.23 \pm 0.06$ & $0.20 \pm 0.03^{*}$ & $0.25 \pm 0.05^{*}$ & $0.25 \pm 0.06^{*}$ \\
\hline Basophils (thou/mm³) & $0.03 \pm 0.01$ & $0.04 \pm 0.01^{*}$ & $0.04 \pm 0.01^{*}$ & $0.05 \pm 0.02^{*}$ \\
\hline Platelets (thou/ $/ \mathrm{mm}^{3}$ ) & $854.00 \pm 3.06$ & $860.67 \pm 12.02^{*}$ & $870.00 \pm 8.19^{*}$ & $835.00 \pm 20.82^{*}$ \\
\hline Mean platelet volume (fl) & $8.00 \pm 0.23$ & $7.83 \pm 0.18^{*}$ & $8.27 \pm 0.27^{*}$ & $8.10 \pm 0.32^{*}$ \\
\hline
\end{tabular}

$\mathrm{Hb}$, Haemoglobin; PVC, Packed cell volume; MCV, Mean corpuscular volume; MCH, Mean corpuscular hemoglobin; MCHC, Mean corpuscular hemoglobin concentration; TLC, Total leucocytes count; RDW, Red cell distribution width; WBC, White blood cell; MPV, Mean platelet volume.

Values represent the mean $\pm \operatorname{SEM}(n=5)$.

" $p>0.05$. 
Table 4. Effects of C. bonducella extract on biochemical parameters in subacute oral toxicity study.

\begin{tabular}{|c|c|c|c|c|}
\hline Parameters & Control & $250 \mathrm{mg} / \mathrm{kg}$ & $500 \mathrm{mg} / \mathrm{kg}$ & $1,000 \mathrm{mg} / \mathrm{kg}$ \\
\hline Urea (mg/dl) & $23.01 \pm 1.79$ & $24.39 \pm 2.11^{*}$ & $24.99 \pm 2.08^{*}$ & $22.64 \pm 1.34^{*}$ \\
\hline Uric acid (mg/dl) & $2.77 \pm 0.66$ & $2.49 \pm 0.60^{*}$ & $2.55 \pm 0.70^{*}$ & $2.92 \pm 0.50^{*}$ \\
\hline Creatinine $(\mathrm{mg} / \mathrm{dl})$ & $0.74 \pm 0.14$ & $0.54 \pm 0.10^{*}$ & $0.49 \pm 0.15^{*}$ & $0.62 \pm 0.11^{*}$ \\
\hline $\operatorname{ALP}(\mathrm{U} / 1)$ & $135.16 \pm 0.55$ & $135.47 \pm 2.90^{*}$ & $133.66 \pm 2.28^{*}$ & $135.42 \pm 1.01^{*}$ \\
\hline $\operatorname{AST}(\mathrm{U} / 1)$ & $75.03 \pm 0.74$ & $75.14 \pm 1.27^{*}$ & $75.82 \pm 2.15^{*}$ & $75.73 \pm 1.01^{*}$ \\
\hline $\operatorname{ALT}(\mathrm{U} / 1)$ & $45.85 \pm 0.85$ & $47.21 \pm 1.57^{*}$ & $47.56 \pm 2.35^{*}$ & $47.23 \pm 1.48^{*}$ \\
\hline Albumin (mg/dl) & $3.63 \pm 0.14$ & $3.59 \pm 0.20^{*}$ & $3.75 \pm 0.05^{*}$ & $3.70 \pm 0.12^{*}$ \\
\hline Globulin (mg/dl) & $3.44 \pm 0.15$ & $3.39 \pm 0.07^{*}$ & $3.42 \pm 0.06^{*}$ & $3.36 \pm 0.09^{*}$ \\
\hline Total protien & $7.07 \pm 0.29$ & $6.97 \pm 0.27^{*}$ & $7.17 \pm 0.09^{*}$ & $7.06 \pm 0.20^{*}$ \\
\hline Albumin/globulin ratio & $1.06 \pm 0.02$ & $1.08 \pm 0.04^{*}$ & $1.11 \pm 0.03^{*}$ & $1.12 \pm 0.03^{*}$ \\
\hline Initial wt (g) & $143.50 \pm 2.17$ & $143.33 \pm 1.78^{*}$ & $141.17 \pm 2.21^{*}$ & $140.33 \pm 1.36^{*}$ \\
\hline 1 week (g) & $148.00 \pm 2.14$ & $147.67 \pm 1.91^{*}$ & $146.67 \pm 2.35^{*}$ & $145.67 \pm 1.15^{*}$ \\
\hline 2 weeks (g) & $153.33 \pm 1.80$ & $151.83 \pm 1.74^{*}$ & $151.00 \pm 2.18^{*}$ & $150.17 \pm 1.17^{*}$ \\
\hline 3 weeks (g) & $157.67 \pm 1.74$ & $157.33 \pm 1.86^{*}$ & $156.00 \pm 2.18^{*}$ & $154.83 \pm 1.25^{*}$ \\
\hline Final weight (g) & $163.00 \pm 1.48$ & $163.33 \pm 1.76^{*}$ & $161.67 \pm 1.98^{*}$ & $161.50 \pm 1.09^{*}$ \\
\hline $\mathrm{BWG}(\mathrm{g})$ & $19.50 \pm 0.89$ & $20.00 \pm 1.15^{*}$ & $20.50 \pm 0.72^{*}$ & $21.17 \pm 1.01^{*}$ \\
\hline Food intake (g/day) & $23.67 \pm 1.33$ & $24.67 \pm 1.12^{*}$ & $22.33 \pm 0.99^{*}$ & $22.00 \pm 0.93^{*}$ \\
\hline Water intake $(\mathrm{ml} /$ day $)$ & $29.83 \pm 1.40$ & $27.33 \pm 1.20^{*}$ & $25.67 \pm 1.54^{*}$ & $28.17 \pm 0.87^{*}$ \\
\hline
\end{tabular}

AST, Aspartate aminotransferase; ALT, Alanine aminotransferase; ALP, Alkaline phosphatase; BWG, Mean bodyweight gain.

Values represent the mean $\pm \operatorname{SEM}(n=5)$.

${ }^{*} p>0.05$.

Table 5. Body weight change during treatment.

\begin{tabular}{|c|c|c|c|c|c|c|}
\hline & & \multicolumn{5}{|c|}{ Body weight (g) } \\
\hline \multirow{3}{*}{$\begin{array}{c}\text { EG-induced } \\
\text { urolithiasis model }\end{array}$} & Initial & $144.4 \pm 2.29$ & $143.4 \pm 1.33$ & $143.6 \pm 1.72 *$ & $142.8 \pm 1.88 *$ & $142.4 \pm 1.72 *$ \\
\hline & 14 days & $158.2 \pm 2.08$ & $139.6 \pm 1.21$ & $138.6 \pm 1.40 *$ & $137.8 \pm 2.01 *$ & $136.8 \pm 1.83 *$ \\
\hline & 28 days & $167.2 \pm 1.12$ & $128.6 \pm 1.12$ & $138 \pm 2.17^{* *}$ & $147.4 \pm 1.96^{* * * *}$ & $149.2 \pm 1.36^{* * * * *}$ \\
\hline \multirow[t]{2}{*}{$\begin{array}{c}\text { SO-induced } \\
\text { urolithiasis model }\end{array}$} & 7 days & $151.4 \pm 3.12$ & $137.4 \pm 2.34$ & $139.2 \pm 1.66^{*}$ & $137.4 \pm 2.69 *$ & $138.6 \pm 2.11 *$ \\
\hline & 21 days & $163.6 \pm 2.18$ & $129.2 \pm 2.18$ & $145.2 \pm 3.04^{* * *}$ & $148.6 \pm 1.81^{* * * * *}$ & $149.2 \pm 4.10^{* * * * *}$ \\
\hline \multirow[b]{2}{*}{$\begin{array}{c}\text { GA-induced } \\
\text { urolithiasis model }\end{array}$} & Initial & $143.2 \pm 3.06$ & $141.2 \pm 2.50$ & $144.4 \pm 2.29 *$ & $142.8 \pm 2.92 *$ & $140.8 \pm 2.87 *$ \\
\hline & 7 days & $150.8 \pm 1.71$ & $137 \pm 2.05$ & $140.8 \pm 1.36^{*}$ & $138.2 \pm 2.96 *$ & $137.2 \pm 1.85 *$ \\
\hline
\end{tabular}

Data are expressed as mean $\pm \operatorname{SEM}(n=5)$.

$* p>0.05 ; * * p 0.01 ; * * p<0.001 ; * * * p<0.0001$ compared with induce control group II.

with the induced control group (Table 5). Administration of EG, $\mathrm{GA}$, and SO caused induction of renal stone formation and led to a significant decrease in body weight in the induced control group when compared with the normal control group. EG, GA, and SO caused body weight loss. After treatment with the 200 $\mathrm{mg} / \mathrm{kg}$ of $C$. bonducella, slight body weight gain was observed; and treatment with $400 \mathrm{mg} / \mathrm{kg}$ of $C$. bonducella, maximum body weight gain was observed which was similar to cystone-treated group. Ahmed et al. (2013); Bawari et al. (2020); Bayir et al. (2011), Shehzad et al. (2021); Kaushik et al., (2019) reported that lithogenic treatment causes a decrease in body weight.

EG, GA, and SO administration cause significant ( $p<$ 0.05 to $p<0.0001)$ increase in the urinary calcium, phosphorus level and significant $(p<0.05$ to $p<0.0001)$ decrease in the urine 


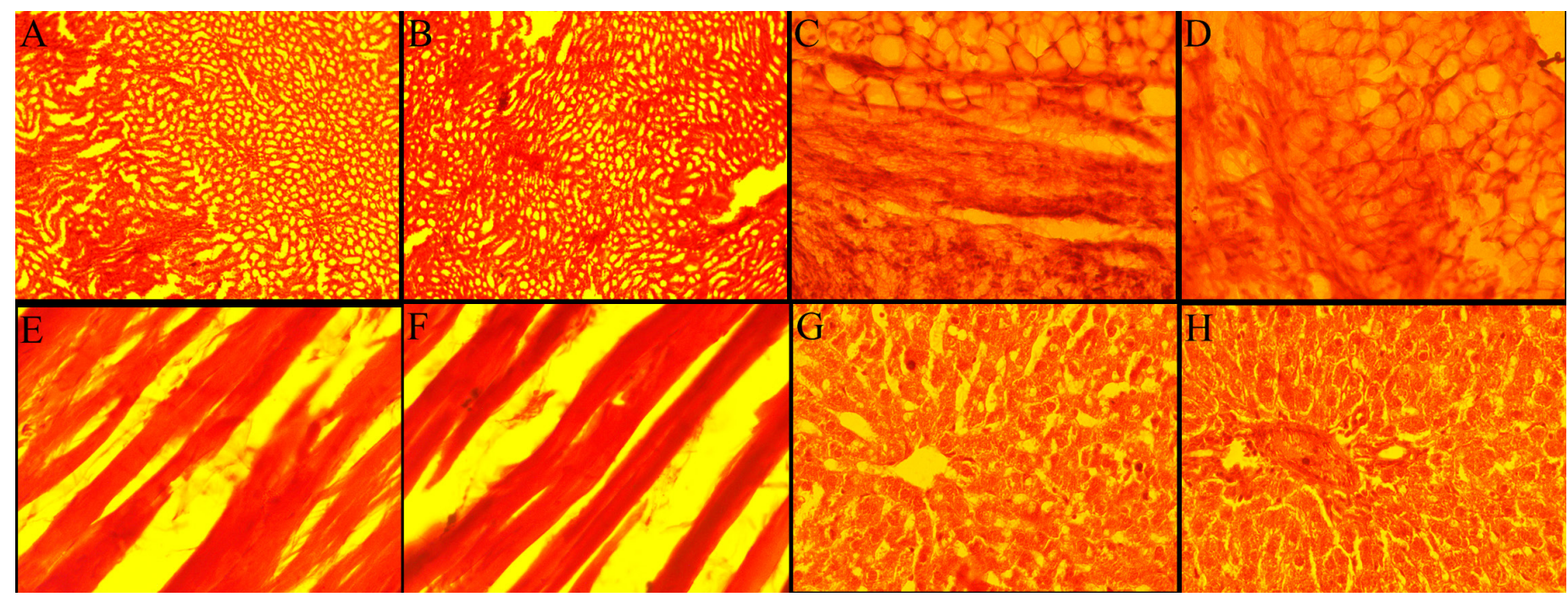

Figure 1. Histology of albino Wistar rat's kidney (A), lung (C), heart (E), liver (G), of the control group and kidney (B), lung (D), heart (F), liver (H) of the group treated with $2,000 \mathrm{mg} / \mathrm{kg}$ dose in acute oral toxicity.

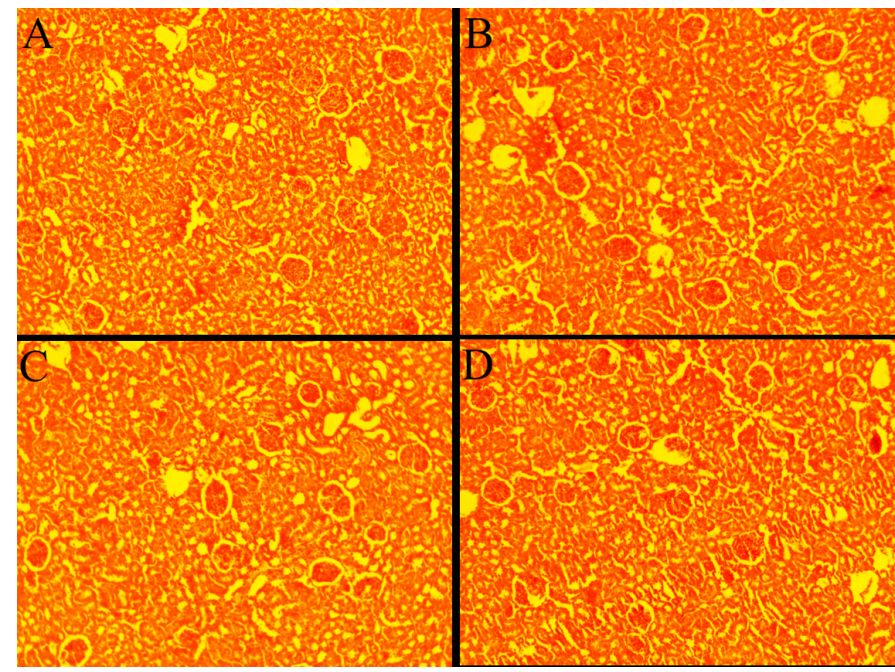

Figure 2. Histology of albino Wistar rat's kidney (A) control group (A) 250 $\mathrm{mg} / \mathrm{kg}(\mathrm{B}), 500 \mathrm{mg} / \mathrm{kg}(\mathrm{C})$, and $1,000 \mathrm{mg} / \mathrm{kg}(\mathrm{D})$ treated group in subacute oral toxicity study.

$\mathrm{pH}$, urine volume, urinary magnesium level in the induced control group as compared with the normal control group. Treatment with 200 and $400 \mathrm{mg} / \mathrm{kg}$ of $C$. bonducella extract causes a significant ( $p$ $<0.05$ to $p<0.0001$ ) decrease in the levels of urinary calcium and phosphorus along with an increase in magnesium urinary level as compared with the induced control group (Table 6). The lithogenic substance decreases the urinary $\mathrm{pH}$ by its metabolism in the acidic compound which causes urinary acidosis. The decrease in urinary $\mathrm{pH}$ favors the $\mathrm{CaOx}$ precipitation by decreasing $\mathrm{CaOx}$ solubility and saturation level in urine which promotes stone formation. Low urinary output also plays a major role by decreasing the volume of urine which got easily supersaturated with oxalates and calcium ions (Patel and Acharya, 2020). The urinary $\mathrm{pH}$ and volume of the induced control group were decreased significantly and urine gets supersaturated with $\mathrm{CaOxs}$, initiating stone formation. Volume

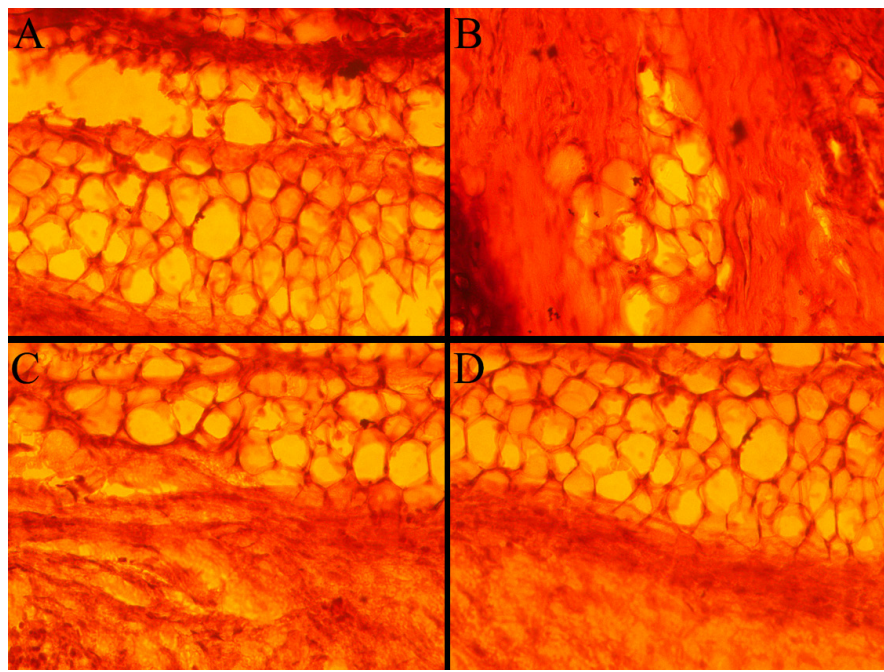

Figure 3. Histology of albino Wistar rat's lung (A) control group (A) $250 \mathrm{mg}$ / $\mathrm{kg}$ (B), $500 \mathrm{mg} / \mathrm{kg}$ (C), and $1,000 \mathrm{mg} / \mathrm{kg}$ (D) treated group in subacute oral toxicity study.

and $\mathrm{pH}$ of urine in C. bonducella extract (200 and $400 \mathrm{mg} / \mathrm{kg}$ ) and cystone-treated group was found significantly increased, which indicates that $\mathrm{CaOx}$ solubility and saturation level were increased in urine. Maximum recovery in urinary parameters were seen with highest dose (i.e., $400 \mathrm{mg} / \mathrm{kg}$ ) which is similar with cystonetreated group.

Urinary magnesium works as an inhibitor in $\mathrm{CaOx}$ stone formation. Magnesium preferentially binds with oxalate and forms a stable complex that is highly water-soluble (Bano et al., 2018; Kaushik et al., 2019). A low level of magnesium is seen in the induced control group and after treatment with the C. bonducella extract, a nearly normal $\mathrm{Mg}$ level was resumed. Increased levels of calcium and phosphorous in the urine favor the growth of $\mathrm{CaOx}$ crystals. Phosphorous as phosphates was deposited on $\mathrm{CaOx}$ stone (Kaushik et al., 2019). The level of 


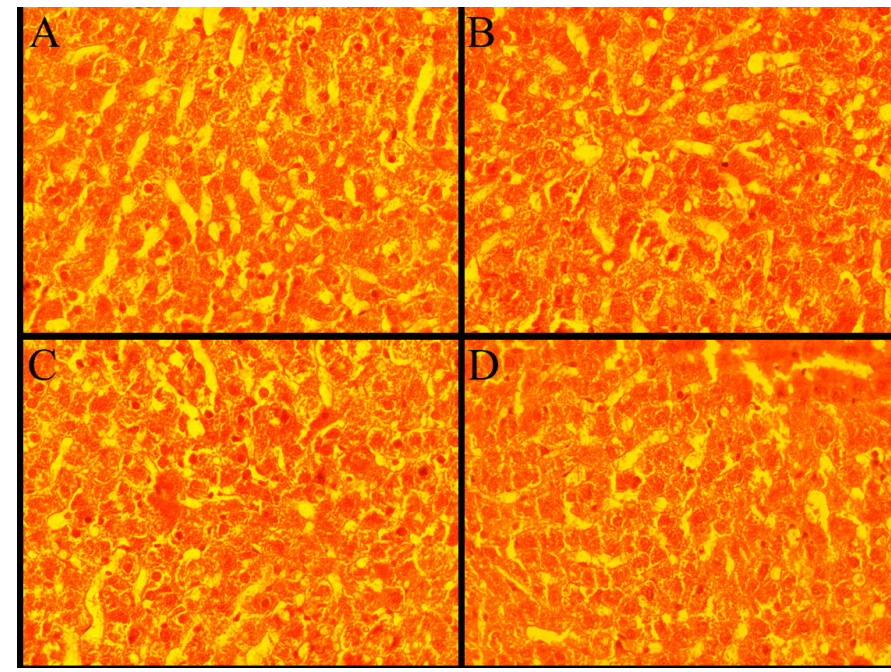

Figure 4. Histology of albino Wistar rat's liver (A) control group (A) $250 \mathrm{mg}$ / $\mathrm{kg}$ (B), $500 \mathrm{mg} / \mathrm{kg}(\mathrm{C})$, and $1,000 \mathrm{mg} / \mathrm{kg}$ (D) treated group in subacute oral toxicity study.

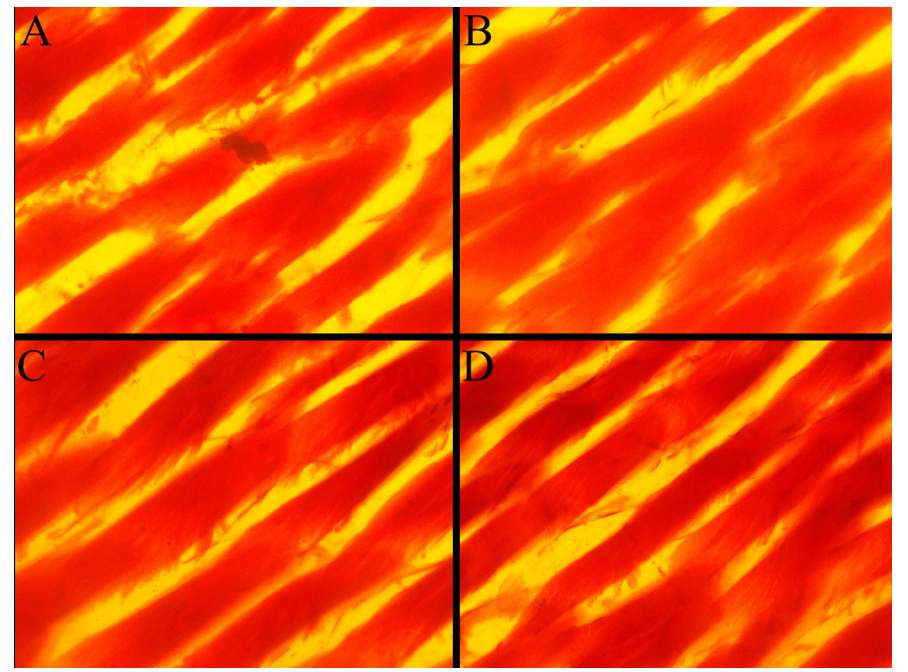

Figure 5. Histology of albino Wistar rat's heart (A) control group (A) $250 \mathrm{mg}$ / $\mathrm{kg}$ (B), $500 \mathrm{mg} / \mathrm{kg}(\mathrm{C})$, and $1,000 \mathrm{mg} / \mathrm{kg}$ (D) treated group in subacute oral toxicity study.

Table 6. Effect of C. bonducella on urine parameter in urolithiasis.

\begin{tabular}{ccccccc}
\hline Model & $\begin{array}{c}\text { Urinary parameters } \\
\text { (per 24 hours) }\end{array}$ & Group I & Group II & Group III & Group IV & Group V \\
\hline & Calcium (mg) & $3.86 \pm 0.09$ & $9.55 \pm 0.16$ & $5.25 \pm 0.13^{* * * *}$ & $4.29 \pm 0.18^{* * * *}$ & $4.05 \pm 0.07^{* * * *}$ \\
& Phosphorous (mg) & $4.08 \pm 0.17$ & $7.36 \pm 0.15$ & $5.89 \pm 0.05^{* * * *}$ & $4.87 \pm 0.07^{* * * *}$ & $4.69 \pm 0.08^{* * * *}$ \\
$\begin{array}{c}\text { EG-induced } \\
\text { urolithiasis } \\
\text { model }\end{array}$ & Magnesium (mg) & $6.52 \pm 0.22$ & $1.03 \pm 0.08$ & $1.72 \pm 0.19^{*}$ & $5.01 \pm 0.12^{* * * *}$ & $5.55 \pm 0.19^{* * * * *}$ \\
& Urine volume ml & $13.65 \pm 0.59$ & $6.25 \pm 0.38$ & $13.80 \pm 0.59^{* * * *}$ & $14.55 \pm 0.25^{* * * *}$ & $12.25 \pm 0.22^{* * * *}$ \\
& Urine pH & $6.74 \pm 0.06$ & $5.30 \pm 0.10$ & $6.22 \pm 0.18^{* * * *}$ & $6.76 \pm 0.11^{* * * *}$ & $6.71 \pm 0.09^{* * * *}$ \\
& Calcium (mg) & $3.02 \pm 0.29$ & $9.04 \pm 0.98$ & $5.55 \pm 0.29^{* * *}$ & $3.80 \pm 0.40^{* * * *}$ & $4.32 \pm 0.28^{* * * *}$ \\
$\begin{array}{c}\text { SO-induced } \\
\text { urolithiasis } \\
\text { model }\end{array}$ & Phosphorous (mg) & $3.88 \pm 0.29$ & $7.78 \pm 0.45$ & $5.69 \pm 0.20^{* * *}$ & $4.97 \pm 0.15^{* * * *}$ & $4.55 \pm 0.18^{* * * *}$ \\
& Urine volume ml & $11.65 \pm 0.71$ & $7.35 \pm 0.33$ & $12.70 \pm 0.59^{* * * *}$ & $13.20 \pm 0.46^{* * * *}$ & $11.95 \pm 0.32^{* * * *}$ \\
& Urine pH & $6.70 \pm 0.10$ & $5.34 \pm 0.13$ & $6.36 \pm 0.15^{* * * *}$ & $6.62 \pm 0.08^{* * * *}$ & $6.74 \pm 0.09^{* * * *}$ \\
& Calcium (mg) & $3.30 \pm 0.39$ & $10.15 \pm 0.59$ & $4.84 \pm 0.31^{* * * *}$ & $3.19 \pm 0.60^{* * * *}$ & $3.35 \pm 0.40^{* * * *}$ \\
& Phosphorous (mg) & $3.63 \pm 0.42$ & $8.09 \pm 0.48$ & $6.01 \pm 0.09^{* * *}$ & $4.08 \pm 0.53^{* * * *}$ & $4.96 \pm 0.26^{* * * *}$ \\
$\begin{array}{c}\text { GA-induced } \\
\text { urolithiasis } \\
\text { model }\end{array}$ & Magnesium (mg) & $7.60 \pm 0.68$ & $0.96 \pm 0.13$ & $3.42 \pm 0.37^{*}$ & $5.55 \pm 0.52^{* * * *}$ & $7.04 \pm 0.84^{* * * *}$ \\
& Urine volume ml & $12.85 \pm 0.35$ & $6.70 \pm 0.22$ & $12.80 \pm 0.50^{* * * *}$ & $13.10 \pm 0.75^{* * * *}$ & $12.15 \pm 0.22^{* * * *}$ \\
& Urine pH & $6.73 \pm 0.10$ & $5.42 \pm 0.12$ & $6.40 \pm 0.08^{* * * *}$ & $6.60 \pm 0.14^{* * * *}$ & $6.71 \pm 0.11^{* * * *}$ \\
\hline
\end{tabular}

Data are expressed as mean $\pm \operatorname{SEM}(n=5)$.

${ }^{*} p<0.05 ;{ }^{* *} p<0.01 ; * * * p<0.001 ; * * * * p<0.0001$ compared with induced control group II.

calcium and phosphorous was decreased in the C. bonducella extract-treated group.

The serum biochemical parameters like uric acid, urea, creatinine, BUN, ALP level were significantly $(p<0.05$ to $<0.0001)$ increased in the induced control group as compared to the normal group. However, these biochemical parameters were found to be significantly ( $p<0.05$ to $<0.0001$ ) decreased in both C. bonducella extract and cystone-treated groups as compared to the induced control group (Table 7). Maximum recovery in biochemical parameters were seen with highest dose (i.e., $400 \mathrm{mg} /$ $\mathrm{kg}$ ) which is similar with cystone-treated group. Stone deposition in tubules and glomerulus obstruct the outflow of urine and decreases 
Table 7. Effect of $C$. bonducella on serum biochemical parameters in urolithiasis

\begin{tabular}{|c|c|c|c|c|c|c|}
\hline Model & Serum parameters & Group I & Group II & Group III & Group IV & Group V \\
\hline \multirow{4}{*}{$\begin{array}{c}\text { EG-induced } \\
\text { urolithiasis model }\end{array}$} & Urea (mg/dl) & $27.72 \pm 2.52$ & $40.68 \pm 2.52$ & $33.92 \pm 1.57^{*}$ & $28.04 \pm 1.28^{* * * *}$ & $31.46 \pm 0.82^{* * *}$ \\
\hline & Uric acid (mg/dl) & $2.618 \pm 0.18$ & $8.024 \pm 0.20$ & $3.22 \pm 0.20^{* * * * *}$ & $2.932 \pm 0.07^{* * * * * *}$ & $2.878 \pm 0.26^{* * * * *}$ \\
\hline & Creatinine (mg/dl) & $0.544 \pm 0.05$ & $1.824 \pm 0.12$ & $0.912 \pm 0.04^{* * * * *}$ & $0.696 \pm 0.05^{* * * * *}$ & $0.65 \pm 0.04^{* * * * *}$ \\
\hline & BUN & $12.95 \pm 0.64$ & $19.00 \pm 1.18$ & $15.84 \pm 0.73^{* *}$ & $13.09 \pm 0.60^{* * * * *}$ & $14.69 \pm 0.38^{* * * *}$ \\
\hline \multirow{5}{*}{$\begin{array}{c}\text { SO-induced } \\
\text { urolithiasis model }\end{array}$} & $\operatorname{ALP}(\mathrm{U} / 1)$ & $139.04 \pm 2.94$ & $183.46 \pm 4.19$ & $172.20 \pm 2.54^{* *}$ & $141.70 \pm 2.95^{* * * * *}$ & $142.84 \pm 0.92^{* * * * * *}$ \\
\hline & Urea $(\mathrm{mg} / \mathrm{dl})$ & $23.40 \pm 4.14$ & $44.39 \pm 4.14$ & $32.01 \pm 2.32^{* *}$ & $25.48 \pm 2.18^{* * *}$ & $22.76 \pm 2.59^{* * * *}$ \\
\hline & Uric acid (mg/dl) & $2.232 \pm 0.22$ & $8.67 \pm 0.38$ & $2.904 \pm 0.30^{* * * * *}$ & $2.616 \pm 0.19^{* * * * * *}$ & $2.772 \pm 0.27^{* * * * *}$ \\
\hline & Creatinine (mg/dl) & $0.642 \pm 0.13$ & $2.478 \pm 0.27$ & $1.072 \pm 0.13^{* * * * *}$ & $0.756 \pm 0.08^{* * * * * *}$ & $0.58 \pm 0.10^{* * * * *}$ \\
\hline & BUN & $10.93 \pm 0.99$ & $20.73 \pm 1.93$ & $14.95 \pm 1.08^{* *}$ & $11.90 \pm 1.02^{* * * *}$ & $10.63 \pm 1.21^{* * * * *}$ \\
\hline \multirow{6}{*}{$\begin{array}{l}\text { GA-induced } \\
\text { urolithiasis model }\end{array}$} & ALP (U/l) & $135.82 \pm 4.60$ & $211.06 \pm 12.74$ & $179.34 \pm 6.89^{* *}$ & $139.28 \pm 4.58^{* * * * * *}$ & $133.68 \pm 2.91^{* * * * *}$ \\
\hline & Urea (mg/dl) & $24.80 \pm 3.18$ & $41.01 \pm 3.18$ & $30.08 \pm 2.81^{* *}$ & $26.33 \pm 2.10^{* * *}$ & $27.04 \pm 2.26^{* * *}$ \\
\hline & Uric acid (mg/dl) & $2.464 \pm 0.45$ & $8.74 \pm 0.80$ & $3.60 \pm 0.47^{* * * * * *}$ & $2.564 \pm 0.34^{* * * * * *}$ & $2.286 \pm 0.48^{* * * * *}$ \\
\hline & Creatinine (mg/dl) & $0.46 \pm 0.09$ & $2.25 \pm 0.24$ & $1.12 \pm 0.21^{* * * * *}$ & $0.50 \pm 0.13^{* * * * * *}$ & $0.38 \pm 0.14^{* * * * * *}$ \\
\hline & BUN & $11.58 \pm 0.78$ & $19.15 \pm 1.49$ & $14.05 \pm 1.31^{* *}$ & $12.30 \pm 0.98^{* * *}$ & $12.63 \pm 1.05^{* * *}$ \\
\hline & $\operatorname{ALP}(\mathrm{U} / 1)$ & $130.42 \pm 5.63$ & $196.35 \pm 7.18$ & $162.50 \pm 8.00^{* * *}$ & $138.06 \pm 4.94^{* * * * * *}$ & $145.98 \pm 3.65^{* * * * * *}$ \\
\hline
\end{tabular}

Data are expressed as mean $\pm \operatorname{SEM}(n=5)$.

${ }^{*} p>0.05 ; * * p<0.05 ; * * * p<0.01 ; * * * * p<0.001 ; * * * * * p<0.0001$ compared with induced control group II.
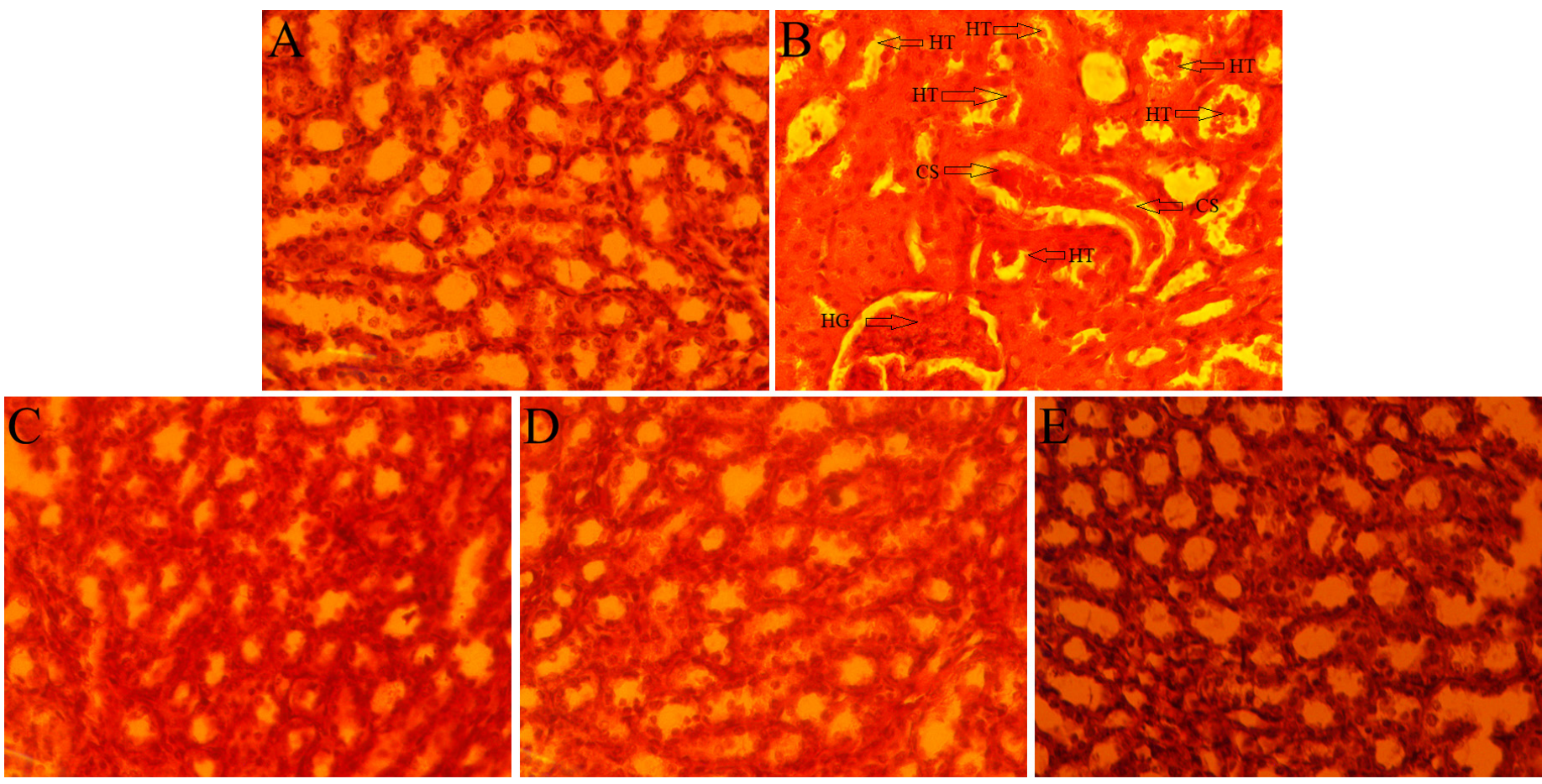

Figure 6. Histology of albino Wistar rat's kidney of the normal control group (A), induced control group (B), $200 \mathrm{mg} / \mathrm{kg}$ (C), $400 \mathrm{mg} / \mathrm{kg}$ (D), and cystone (E) treated group in EG-induced urolithiasis model. 


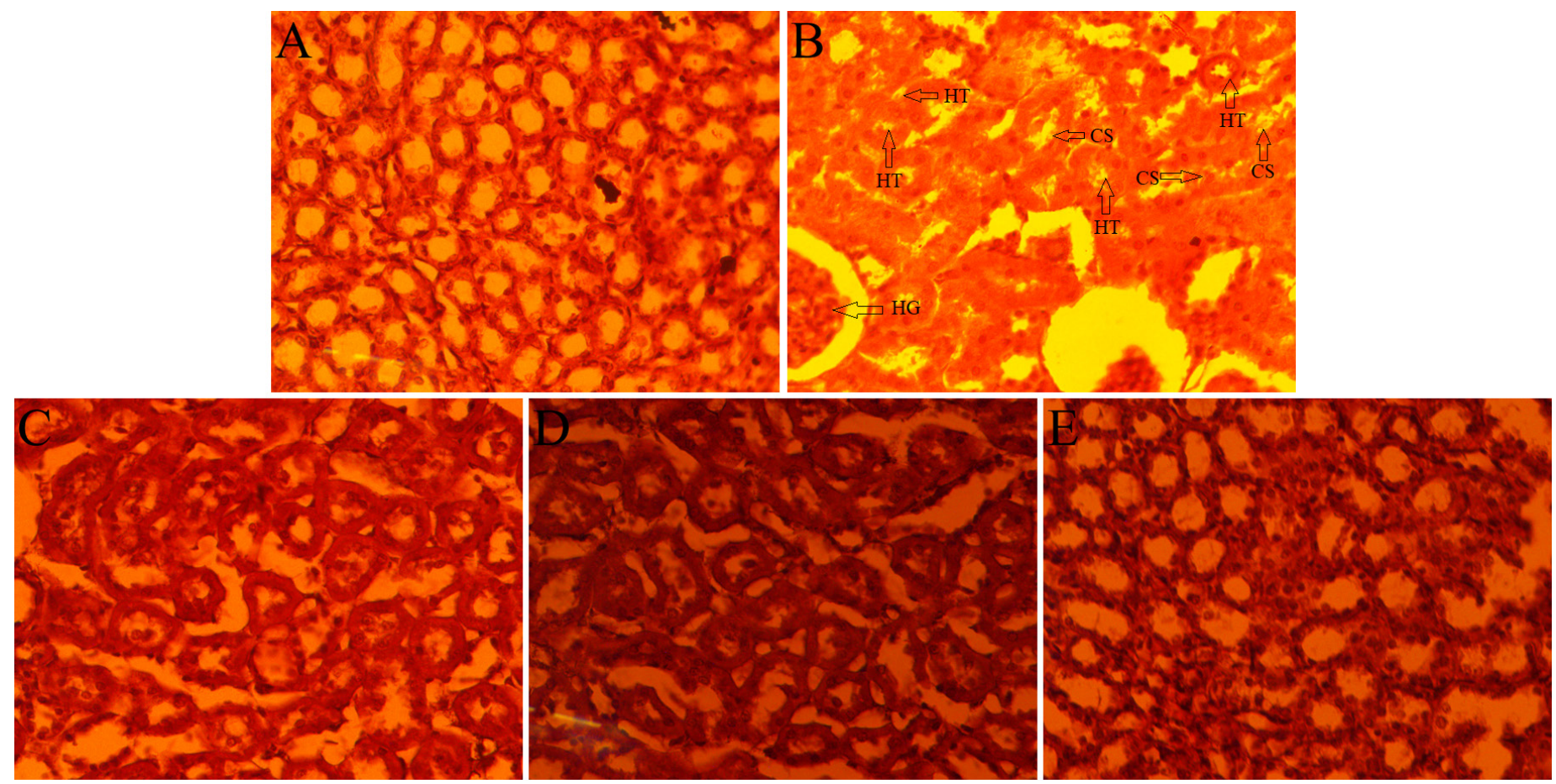

Figure 7. Histology of albino Wistar rat's kidney of the normal control group (A), induced control group (B), $200 \mathrm{mg} / \mathrm{kg}$ (C), $400 \mathrm{mg} / \mathrm{kg}$ (D), and cystone (E) treated group in GA-induced urolithiasis model.
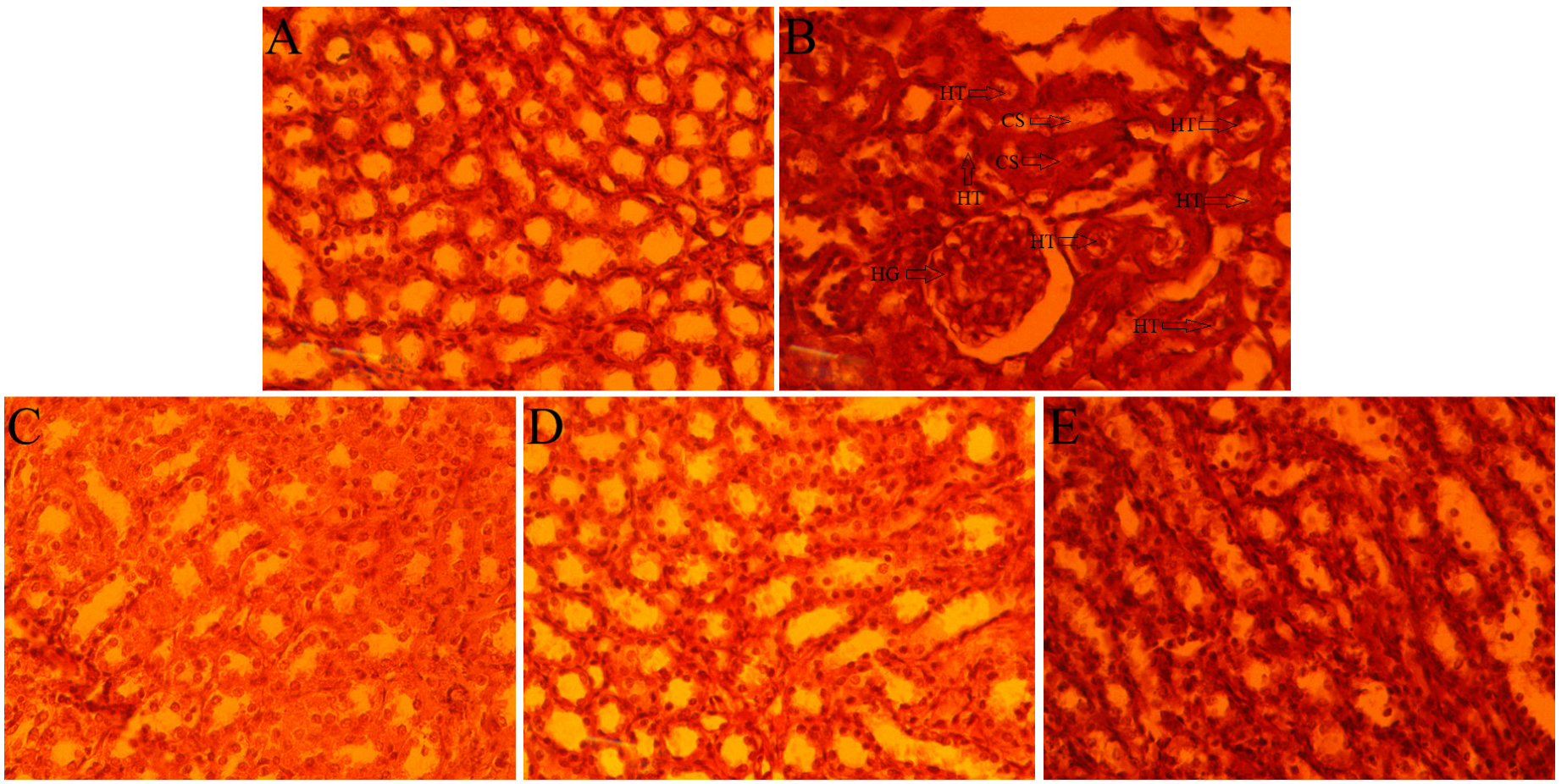

Figure 8. Histology of albino Wistar rat's kidney of the normal control group (A), induced control group (B), $200 \mathrm{mg} / \mathrm{kg}$ (C), $400 \mathrm{mg} / \mathrm{kg}$ (D), and cystone (E) treated group in SO-induced urolithiasis model. 
the glomerular filtration rate which leads to the accumulation of nitrogenous waste products (urea, BUN, creatinine, and uric acid) in the blood (Bano et al., 2018; Bayir et al., 2011; Kaushik et al., 2019). However, the accumulation of nitrogenous waste in blood was reduced on treatment with $C$. bonducella extract. ALP level is a marker for kidney damage. In urolithiasis, apical membranes of renal tubular epithelial are damaged because of $\mathrm{CaOx}$ crystals deposition. This membrane damage leads to a rise in ALP (Kaushik et al., 2019).

The histopathological section of the kidney showed a mild increase in glomerular hypercellularity with severe tubular hydropic degeneration and casts in EG induced control group (Fig. 6B); moderate increased glomerular hypercellularity with moderate tubular hydropic degeneration and casts in GA induced control group (Fig. 7B); moderate increased glomerular hypercellularity, mild tubular hydropic degeneration and casts in SO-induced control group (Fig. 8B) as compared with the respective normal control group. In $C$. bonducella extract (200 and $400 \mathrm{mg} / \mathrm{kg}$ ) treated rat's kidney section showed that glomerular hypercellularity, tubular hydropic degeneration, and casts were recovered in a concentration-dependent manner (Figs. $6 \mathrm{C}$ and $\mathrm{D}, 7 \mathrm{C}$ and $\mathrm{D}, 8 \mathrm{C}$ and $\mathrm{D})$; and rats in the cystone-treated group were also recovered (Figs. 6E, 7E and 8E) as compared with the respective induced control group.

\section{CONCLUSION}

From the above results, it can be concluded that the ethanolic extract of $C$. bonducella has no toxic effect on albino Wistar rats in an acute and subacute oral study. $400 \mathrm{mg} / \mathrm{kg}$ of $C$. bonducella seed extract showed preventive effect in experimentally EG, GA, and SO-induced urolithiasis by normalizing imbalanced electrolytes in urine, nitrogenous substances in serum, and decreasing supersaturation of $\mathrm{CaOx}$. Therefore, it is concluded that $400 \mathrm{mg} / \mathrm{kg}$ of $C$. bonducella seed extract could be used as a therapeutic agent to prevent urolithiasis and attenuate the problems associated with it.

\section{ACKNOWLEDGMENTS}

The authors would like to acknowledge the facility provided by the Department of Pharmacology, Institute of Medical Sciences, Banaras Hindu University, Varanasi, India.

\section{AUTHOR CONTRIBUTIONS}

All authors made substantial contributions to conception and design, acquisition of data, or analysis and interpretation of data; took part in drafting the article or revising it critically for important intellectual content; agreed to submit to the current journal; gave final approval of the version to be published; and agree to be accountable for all aspects of the work. All the authors are eligible to be an author as per the international committee of medical journal editors (ICMJE) requirements/guidelines.

\section{FUNDING}

There is no funding to report.

\section{CONFLICTS OF INTEREST}

The authors report no financial or any other conflicts of interest in this work.

\section{ETHICAL APPROVALS}

All the experimental procedures were approved by the ethical committee of the Institute of Medical Sciences, BHU, Varanasi, India $(2211,07.11 .2020)$ for the care and use of Laboratory Animals.

\section{DATA AVAILABILITY}

All data generated and analyzed are included within this research article.

\section{PUBLISHER'S NOTE}

This journal remains neutral with regard to jurisdictional claims in published institutional affiliation.

\section{REFERENCES}

Ahmed A, Wadud A, Jahan N, Bilal A, Hajera S. Efficacy of Adiantum capillus veneris Linn in chemically induced urolithiasis in rats. $\mathrm{J}$ Ethnopharmacol, 2013; 146(1):411-6.

Ahmed S, Hasan MM, Khan H, Mahmood ZA, Patel S. The mechanistic insight of polyphenols in calcium oxalate urolithiasis Mitigation. Biomed Pharmacother, 2018; 106:1292-9.

Araújo DL, Costa-Pessoa JM, de Ponte MC, Oliveira-Souza M. Sodium oxalate-induced acute kidney injury associated with glomerular and tubulointerstitial damage in rats. Front Physiol, 2020; 11:1076.

Arif T, Mandal TK, Kumar N, Bhosale JD, Hole A, Sharma GL, Padhib MM, Lavekarb GS, Dabur R. In vitro and in vivo antimicrobial activities of seeds of Caesalpinia bonduc (Lin.) Roxb. J Ethnopharmacol, 2009; 123(1):177-80.

Bano H, Jahan N, Makbul SAA, Kumar BN, Husain S, Sayed A. Effect of Piper cubeba L. fruit on ethylene glycol and ammonium chloride induced urolithiasis in male Sprague Dawley rats. Integr Med Res, 2018; 7(4):358-65.

Bashir S, Gilani AH. Antiurolithic effect of Bergenia ligulata rhizome: an explanation of the underlying mechanisms. J Ethnopharmacol, 2009; 122(1):106-16.

Bawari S, Sah AN, Tewari D. Anticalcifying effect of Daucus carota in experimental urolithiasis in Wistar rats. J Ayurveda Integr Med, 2020; 11(3):308-15.

Bayir Y, Halici Z, Keles MS, Colak S, Cakir A, Kaya Y, Akcay F. Helichrysum plicatum DC. subsp. plicatum extract as a preventive agent in experimentally induced urolithiasis model. J Ethnopharmacol, 2011; 138(2):408-14.

Besiroglu H, Ozbek E. Association between blood lipid profile and urolithiasis: a systematic review and meta-analysis of observational studies. Int J Uro, 2019; 26(1):7-17.

Datte JY, Traore A, Offoumou AM, Ziegler A. Effects of leaf extract of Caesalpinia bonduc (Caesalpiniaceae) on the contractile activity of uterine smooth muscle of pregnant rats. J Ethnopharmacol, 1998; 60(2):149-55.

Dawson $\mathrm{CH}$, Tomson CRV. Kidney stone disease: pathophysiology, investigation and medical treatment. Clin Med, 2012; 12(5):467-71.

Ekanayake CP, Thammitiyagodage MG, Padumadasa S, Seneviratne B, Padumadasa C, Abeysekera AM. Acute and subacute toxicity studies of the ethyl acetate soluble proanthocyanidins of the immature inflorescence of Cocos nucifera L. in female Wistar rats. BioMed Res Int, 2019; 2019:8428304; doi:10.1155/2019/8428304

Elhan M, Ergene B, Süntar I, Özbilgin S, ÇitoLlu GS, Demirel MA, Keles H, Altun L, Akkol EK. Preclinical evaluation of antiurolithiatic activity of Viburnum opulus L. on sodium oxalate-induced urolithiasis rat model. Evid Based Complement Alternat Med, 2014; 2014:578103; doi:10.1155/2014/578103

Han C, Kim M, Moon S, Jeon Y, Hwang J, Nam C, Park C, Lee S, Na J, Park C, Park H, Lee J, Jang H, Park S, Han K, Choi YW, Lee HY, 
Kang J. Acute and 28-day subacute toxicity studies of hexane extracts of the roots of Lithospermum erythrorhizon in Sprague-Dawley rats. Toxicol Res, 2015; 31(4):403-14.

Hasan M, Mahmud AA, Alam MJ, Siddiqui SA, Arman MSI, Mahmud MH, Amin MN, Imtiaz O, Shahriar M, Jakaria M. Subacute oral toxicity of ayurvedic anti-diabetic preparation Jambadyarista in SpragueDawley rats. Toxicol Rep, 2020; 7:1616-21.

Iheagwam FN, Ogunlana OO, Ogunlana OE, Isewon I, Oyelade J. Potential anti-cancer flavonoids isolated from Caesalpinia bonduc young twigs and leaves: molecular docking and in silico studies. Bioinfo Bio Insights, 2019; 13:1177932218821371; doi:10.1177/1177932218821371

Kaushik J, Tandon S, Bhardwaj R, Kaur T, Singla SK, Kumar J, Tandon C. Delving into the antiurolithiatic potential of Tribulus terrestris extract through in-vivo efficacy and preclinical safety investigations in Wistar rats. Sci Rep, 2019; 9:15969; doi:10.1038/s41598-019-52398-w

Kharchoufa L, Bouhrim M, Bencheikh N, Assri SE, Amirou A, Yamani A, Choukri M, Mekhfi H, Elachouri M. Acute and subacute toxicity studies of the aqueous extract from Haloxylon scoparium Pomel (Hammada scoparia (Pomel)) by oral administration in rodents. BioMed Res Int, 2020; 2020:4020647.

Liu T, Wang M, Qi S, Shen X, Wang Y, Jing W, Yang Y, Li X, Gao H. New cassane-type diterpenoids from kernels of Caesalpinia bonduc (Linn.) Roxb. and their inhibitory activities on phosphodiesterase (PDE) and nuclear factor-kappa B (NF-kB) expression. Bioorg Chem, 2020; 96:103573; doi:10.1016/j.bioorg.2020.103573

Loha M, Mulu A, Abay SM, Ergete W, Geleta B. Acute and subacute toxicity of methanol extract of Syzygium guineense leaves on the histology of the liver and kidney and biochemical compositions of blood in rats. Evid Based Complement Alternat Med, 2019; 10:5702159.

Lonkala S. In-vitro anti-urolithiatic evaluation of tamsulosin against urolithiasis induced in Wistar albino rats. J Forensic Sci Toxicol, 2020; 3(1): 1011

Meguellati H, Ouafi S, Saad S, Djemouai N. Evaluation of acute, subacute oral toxicity and wound healing activity of mother plant and callus of Teucrium polium L. subsp. geyrii Maire from Algeria. South Afri J Bot, $2019 ; 127: 25-34$.

Mitra SK, Gopumadhavan S, Venkataranganna MV, Sundaram R. Effect of cystone, a herbal formulation, on glycolic acid-induced urolithiasis in rats. Phytother Res, 1998; 12(5):372-4.

Moriyama MT, Suga K, Miyazawa K, Tanaka T, Higashioka M, Noda K, Oka M, Tanaka M, Suzuki K. Inhibitions of urinary oxidative stress and renal calcium level by an extract of Quercus salicina Blume/ Quercus stenophylla Makino in a rat calcium oxalate urolithiasis model. Int J Uro, 2009; 16(4):397-401.
Namburu SL, Dodoala S, Koganti B, Prasad KVSRG. Antiurolithiatic activity of Phaseolus vulgaris seeds against ethylene glycolinduced renal calculi in Wistar rats. Int J Gre Pharm, 2017; 11(4):281-9.

Patel VB, Acharya N. Effect of Macrotyloma uniflorum in ethylene glycol induced urolithiasis in rats. Heliyon, 2020; 6(6):e04253.

Porwal M, Khan NA, Maheshwari KK. Evaluation of acute and subacute oral toxicity induced by ethanolic extract of Marsdenia tenacissima leaves in experimental rats. Sci Pharm, 2017; 85(3):29.

Sathya M, Kokilavani R. Antiurolithiatic activity of ethanolic root extract of Saccharum spontaneum on glycolic acid induced urolithiasis in rats. J Drug Del Therap, 2012; 2(5):86-9.

Shehzad A, Saleem U, Shah MA, Cruz CVL, Khan AH, Ahmad B. Antiurolithic evaluation of Cucurbita pepo seeds extract against sodium oxalate-induced renal calculi. Pharmacog Mag, 2021; 16(68):174-80.

Silva MGB, Aragão TP, Vasconcelos CFB, Ferreira PA, Andrade BA, Costa IMA, Costa-Silva JH, Wanderley AG, Lafayette SSL. Acute and subacute toxicity of Cassia occidentalis L. stem and leaf in Wistar rats. J Ethnopharmacol, 2011; 136(2):341-6.

Tzou DT, Taguchi K, Chi T, Stoller ML. Animal models of urinary stone disease. Int J Surg, 2016; 36(Pt D):596-06.

Wang X, Wang M, Ruan J, Zhao S, Xiao J, Tian Y. Identification of urine biomarkers for calcium-oxalate urolithiasis in adults based on UPLC-Q-TOF/MS. J Chromat B. 2019; 1124:290-7.

Yasui T, Okada A, Hamamoto S, Ando R, Taguchi K, Tozawa K, Kohri K. Pathophysiology-based treatment of urolithiasis. Int J Uro, 2017; 24(1):32-8

How to cite this article:

Kumar A, Nandi MK, Kumar B, Kumar A, Kumar R, Kailashiya V, Singh AK. Toxicity (acute and subacute) assessment and in-vivo antiurolithiatic activity of ethanolic extract of Caesalpinia bonducella seed in albino Wistar rat. J Appl Pharm Sci, 2022; 12(02):187-197. 